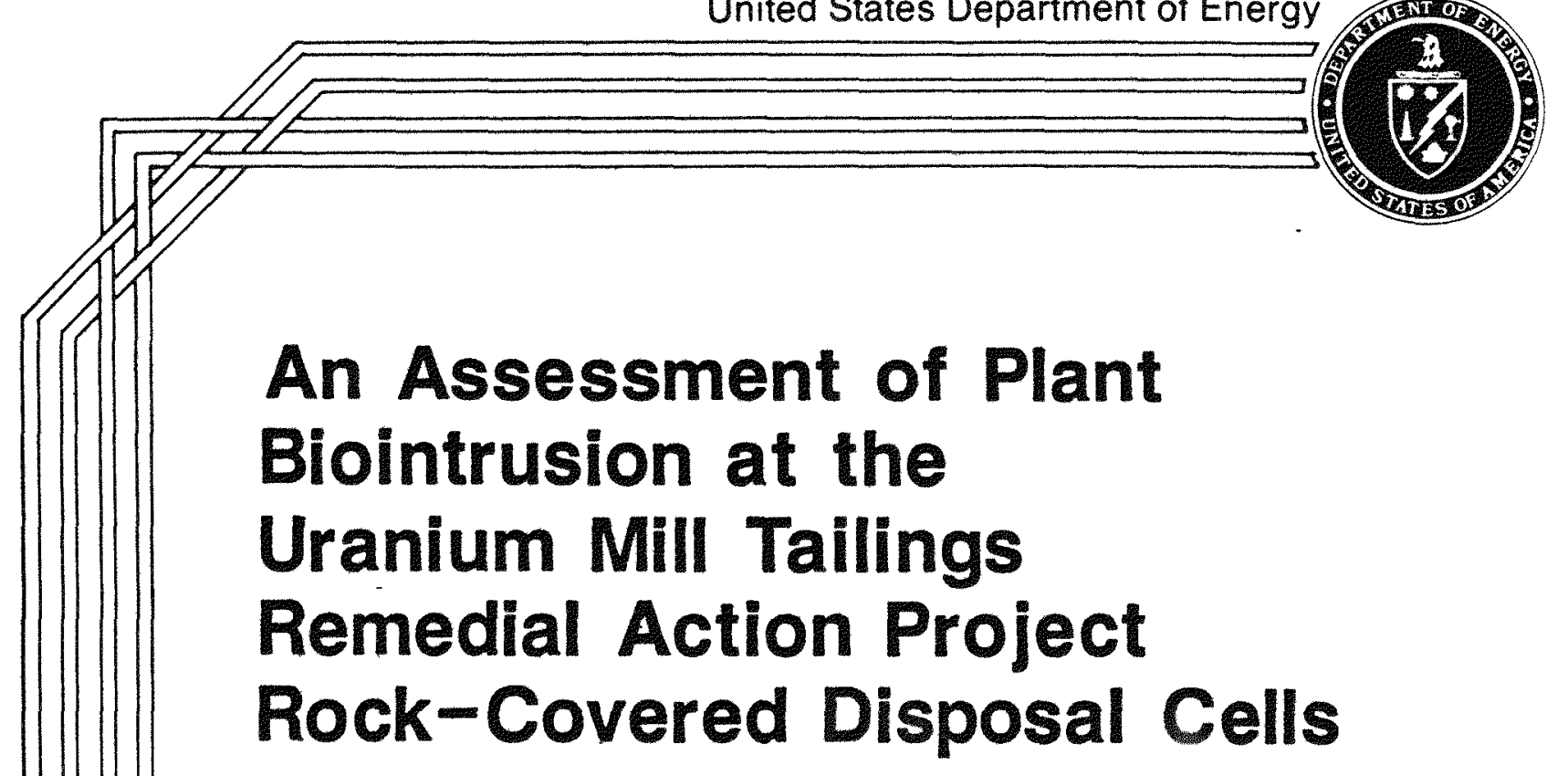

\title{
October 1990
}

\section{DISCLAIMER}

This report was prepared as an account of work sponsored by an agency of the United States Government. Neither the United States Government nor any agency thereof, nor any of their employees, makes any warranty, express or implied, or assumes any legal liability or responsibility for the accuracy, completeness, or usefulness of any information, apparatus, product, or process disclosed, or represents that its use would not infringe privately owned rights. Reference herein to any specific commercial product, process, or service by trade name, trademark, manufacturer, or otherwise does not necessarily constitute or imply its endorsement, recommendation, or favoring by the United States Government or any agency thereof. The views and opinions of authors expressed herein do not necessarily state or reflect those of the United States Government of any agency thereof.

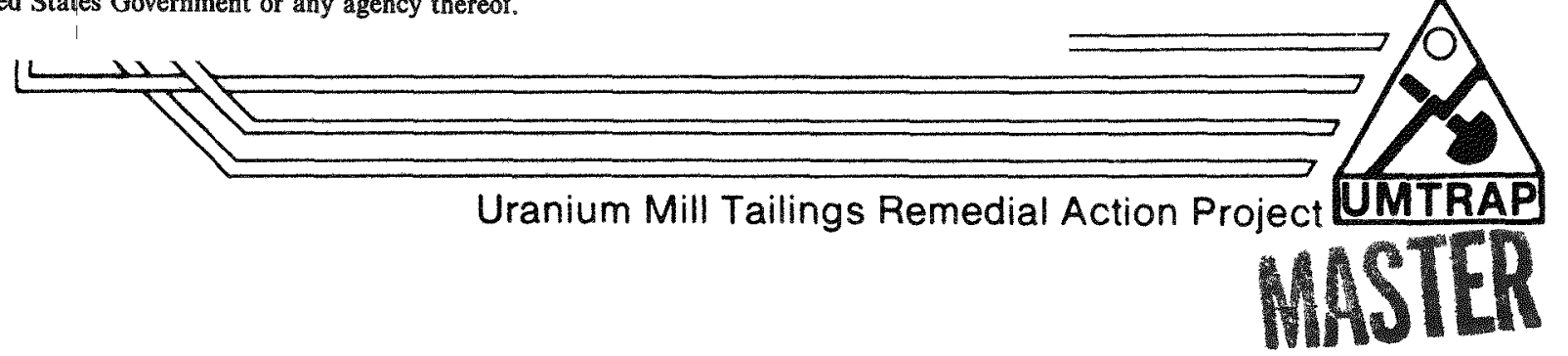




\section{DISCLAIMER}

This report was prepared as an account of work sponsored by an agency of the United States Government. Neither the United States Government nor any agency Thereof, nor any of their employees, makes any warranty, express or implied, or assumes any legal liability or responsibility for the accuracy, completeness, or usefulness of any information, apparatus, product, or process disclosed, or represents that its use would not infringe privately owned rights. Reference herein to any specific commercial product, process, or service by trade name, trademark, manufacturer, or otherwise does not necessarily constitute or imply its endorsement, recommendation, or favoring by the United States Government or any agency thereof. The views and opinions of authors expressed herein do not necessarily state or reflect those of the United States Government or any agency thereof. 


\section{DISCLAIMER}

Portions of this document may be illegible in electronic image products. Images are produced from the best available original document. 
DOE/UMTRA--400662-0000

DE93 009467

\author{
AN ASSESSMENT OF PLANT BIOINTRUSION AT THE \\ URANIUM MILL TAILINGS REMEDIAL ACTION PROJECT \\ ROCK-COVERED DISPOSAL CELLS
}

OCTOBER 1990

\begin{abstract}
U.S. Department of Energy UMTRA Project Office A7buquerque Operations office

Albuquerque, New Mexico
\end{abstract}




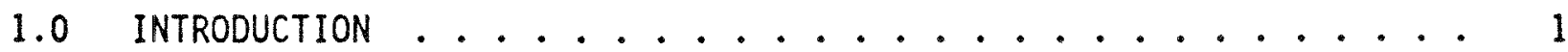

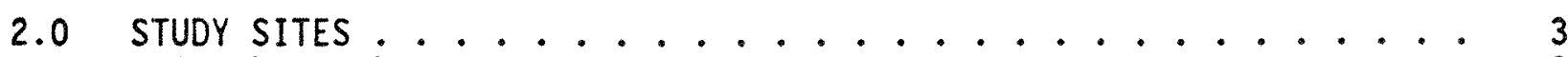

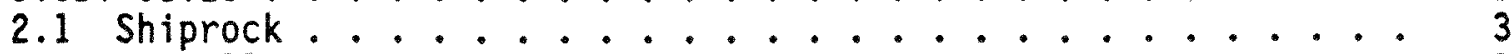

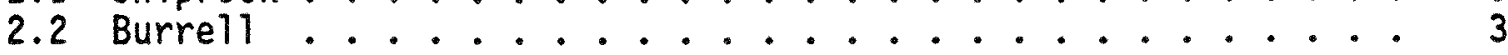

3.0 FIELD METHODS AND RESULTS .................... 9

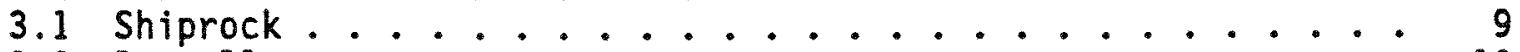

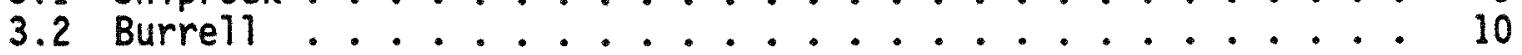

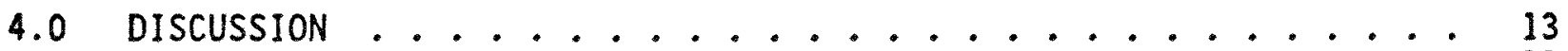

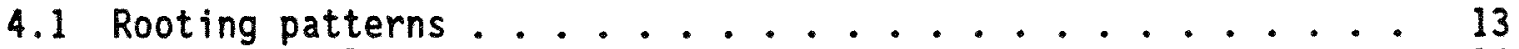

4.2 Impacts analysis .................... 14

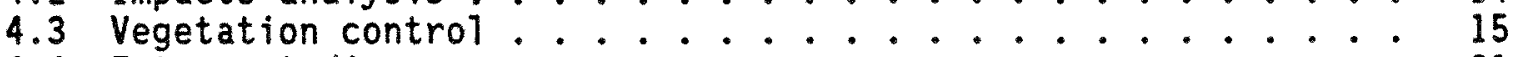

4.4 Future studies................... 21

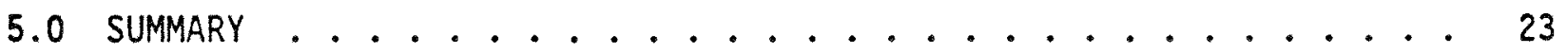

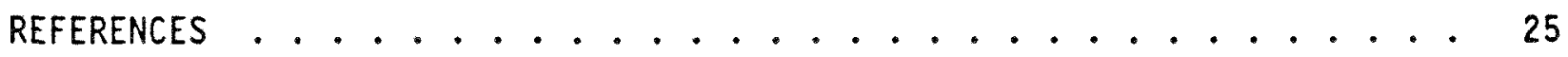

APPENDIX A

PHOTOGRAPHIC SERIES 1: BURRELL DISPOSAL CELL, JULY 19, 1990

PHOTOGRAPHIC SERIES 2: BURRELL DISPOSAL CELL WETLANDS, JULY 19, 1990

PHOTOGRAPHIC SERIES 3: SHIPROCK DISPOSAL CELL, APRIL 4, 1990

PHOTOGRAPHIC SERIES 4: BURRELL DISPOSAL CELL, 1988, 1989, and 1990 


\section{LIST OF FIGURES}

Figure

Page

2.1 Location of Shiprock, New Mexico, disposal site ..........4 4

2.2 Typical cross sections .............. 5

2.3 Location of Burre11, Pennsylvania, disposai site ...... 6

4.1 Typical cross sections for Morris and Fraley (1989) and UMTRA Project disposal cells .............. 17

\section{LIST OF TABLES}

Table

Page

3.1 Plant species observed at the Burre11, Pennsylvania, disposal cell on July 18 and 19,1990 ........... 11

4.1 Existing and proposed erosion protection layers for UMTRA Project disposal cells .............. 18 


\subsection{INTRODUCTION}

This study is one of a number of special studies that have been conducted regarding various aspects of the Uranium Mill Tailings Remedial Action (UMTRA) Project. The UMTRA Project is administered by the U.S. Department of Energy (DOE) pursuant to the Uranium Mill Tailings Radiation Control Act (UMTRCA) enacted by Congress in 1978 (Public Law 95-604), in which Congress authorized the DOE to clean up 24 inactive uranium mill sites. As cleanup actions have been completed at UMTRA Project sites, certain aspects of the disposal ce11's function have generated questions that the special studies are designed to address.

This special study was proposed following routine surveillance and maintenance surveys and observations reported in a special study of vegetative covers (DOE, 1988), in which plants were observed growing up through the rock erosion layer at recently completed disposal cells. Some of the piants observed were deep-rooted woody species, and questions concerning root intrusion into disposal cells and the need to control plant growth were raised. The special study discussed in this report was designed to address some of the ramifications of plant growth on disposal cells that have rock covers.

The "Technical Summary of the UMTRA Project Technology Development Program $(1980-1984) "$ (DOE, 1985) states:

". . a substantial cover thickness of rock riprap on the top and sides of the pile will satisfy requirements for control of animal burrowing and root penetration."

However, no information is given regarding what constitutes "substantial cover thickness;" the rock thickness used on the completed UMTRA disposal cells may not be adequate to prevent root penetration. In addition, the U.S. Nuclear Regulatory Commission's (NRC) recent report, "Final Staff Technical Position-Design of Erosion Protection Covers for Stabilization of Uranium Mill Tailings Sites" (NRC, 1990) states:

"In arid portions of the western United States, the use of a rock cover of acceptable durability is considered by the NRC staff to be the preferred method for satisfying the long-term stability requirements of 40 CFR Part 192 and 10 CFR Part 40, Appendix A."

The NRC has chosen rock covers over vegetative covers in the arid western United States because licenses cannot substantiate that the vegetative covers "will be significantly greater than 30 percent and preferably 70 percent, "which is the amount of "vegetation required to reduce flow to a point of stability." The potential impacts of vegetation growing in rock covers are not addressed by the NRC (1990).

The objectives, then, of this study were to determine the species of plants growing on two rock-covered disposal cells, study the rooting pattern of plants on these cells, and identify possible impacts of plant root penetration on these and other UMTRA Project rock-covered cells. 


$$
-2-
$$




\subsection{STUDY SITES}

Observations were made of plant growth at the Shiprock, New Mexico, and Burre11, Pennsylvania, UMTRA Project sites. The residual radioactive materials, or tailings, at these sites are covered by a three-part system consisting of a radon/infiltration barrier layer, bedding layer, and rock erosion layer. The radon/infiltration barrier layer consists of highly compacted clay placed at a specified moisture content. This layer is designed to limit radon emanation from the radioactive material to a level at or below the U.S. Environmental Protection Agency (EPA) standards and to limit infiltration into the tailings. The bedding layer is a mixture of silt, sand, and gravel that is engineered to support the rock erosion layer, prevent the rock from penetrating the radon/infiltration barrier, and reduce or prevent the erosion of the radon/infiltration barrier. The rock cover is designed to prevent water and wind erosion from affecting the stability of the disposal cell.

\subsection{SHIPROCK}

The Shiprock disposal cell is in northwestern New Mexico (Figure 2.1). The site is arid, receiving approximately six inches of rain per year. It is bordered on the east by the San Juan River and its associated floodplain. The river area contains cottonwoods (Populus fremontii), saltcedar (Tamarix pentandra), greasewood (Sarcobatus vermiculatus), and numerous annual and perennial forbs and grasses. The rest of the site is bordered by areas of relatively disturbed land with a sparse vegetative cover (15 percent) that contains fourwing saltbush (Atriplex canescens), shadscale (Atriplex confertifolia), Russian thistle (Salsola kali), kochia (Kochia americana), Indian ricegrass (Oryzopsis hymenoides), and several other grasses and a few cactus species (DOE, 1984).

The Shiprock disposal cell was completed in September 1986. A total of 1.9 million cubic yards (cy) of residual radioactive materials were encapsulated within the 72-acre disposal cell. The cover system consists of a 6.5 to 7.0foot-thick compacted clay radon/infiltration barrier, a six-inch-thick bedding layer, and a one-foot-thick rock erosion layer (Figure 2.2). The topslopes of the pile have a two-to four-percent slope while the sideslopes have a 20 percent slope. The bedding layer is a mostly silty sand with some gravel. The rock on the sideslopes is smooth river rock 12 to 20 inches in diameter. The topslope is covered with cobbles three to six inches in diameter.

\subsection{BURRELL}

The Burrell disposal cell is in southwestern Pennsylvania approximately 40 miles east of Pittsburgh (Figure 2.3). The site is north of the Conemaugh River and south of the Conrail Railroad tracks. The average annual rainfall at the site is 44.4 inches (DOE, 1983) and the land around the cell is densely vegetated. The cell is bordered on the north and east by an old field plant community dominated by grasses, including fescue (Festuca spp.) and ryegrass (Lolium spp.), and herbaceous species such as teasel (Dipsacus sylvestris), burdock (Arctium minus), goldenrod (Solidago spp.), common mullein (Verbascum thapsus), Queen Anne's lace (Daucus carota), and birdfoot trefoil (Lotus corniculatus) (Appendix A, Photographic series 1). There is a thin strip of recently developed wetlands growing along the north and east edges of the pile, with such species 


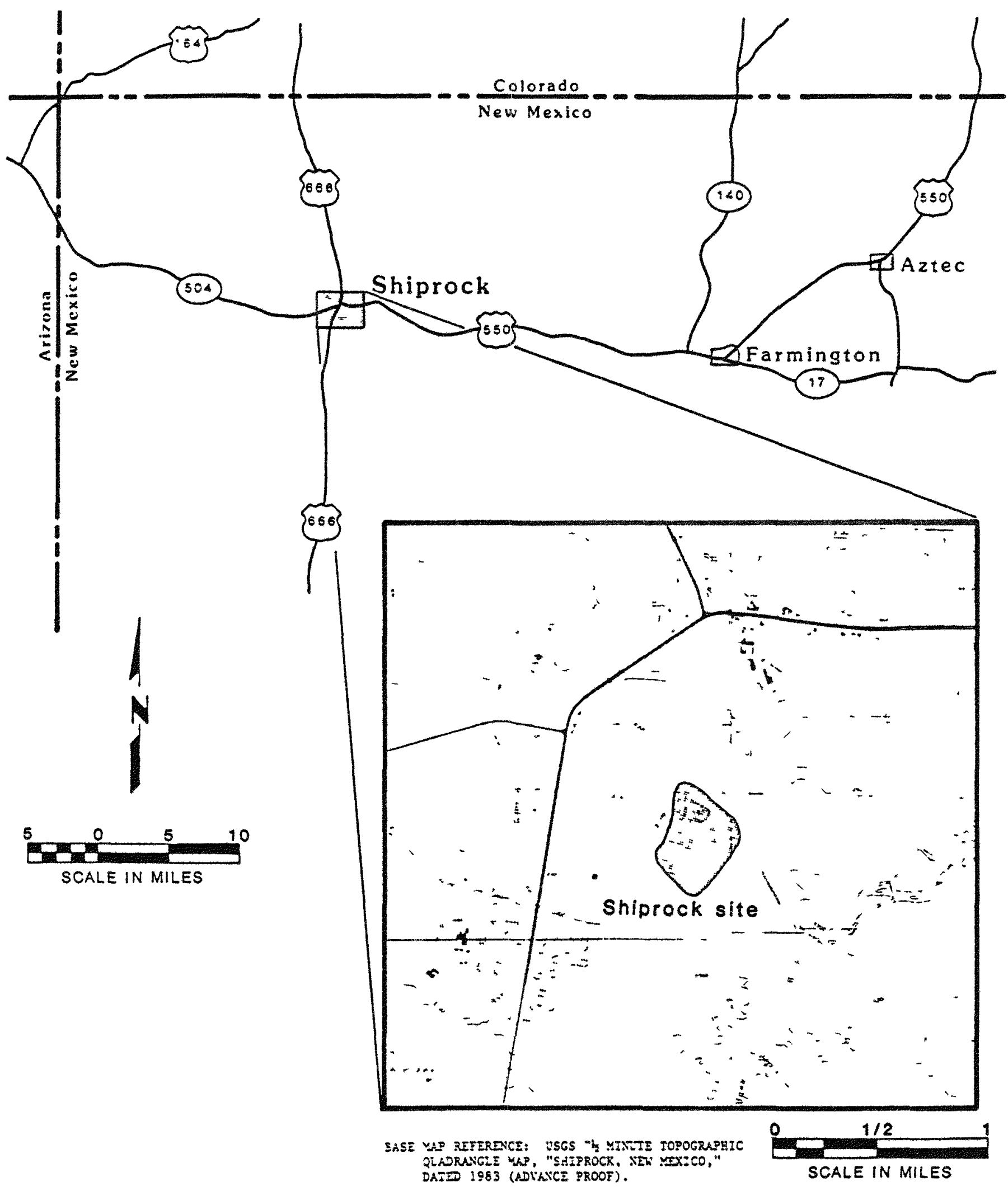

FIGURE 2.1

LOCATION OF SHIPROCK, NEW MEXICO, DISPOSAL SITE 


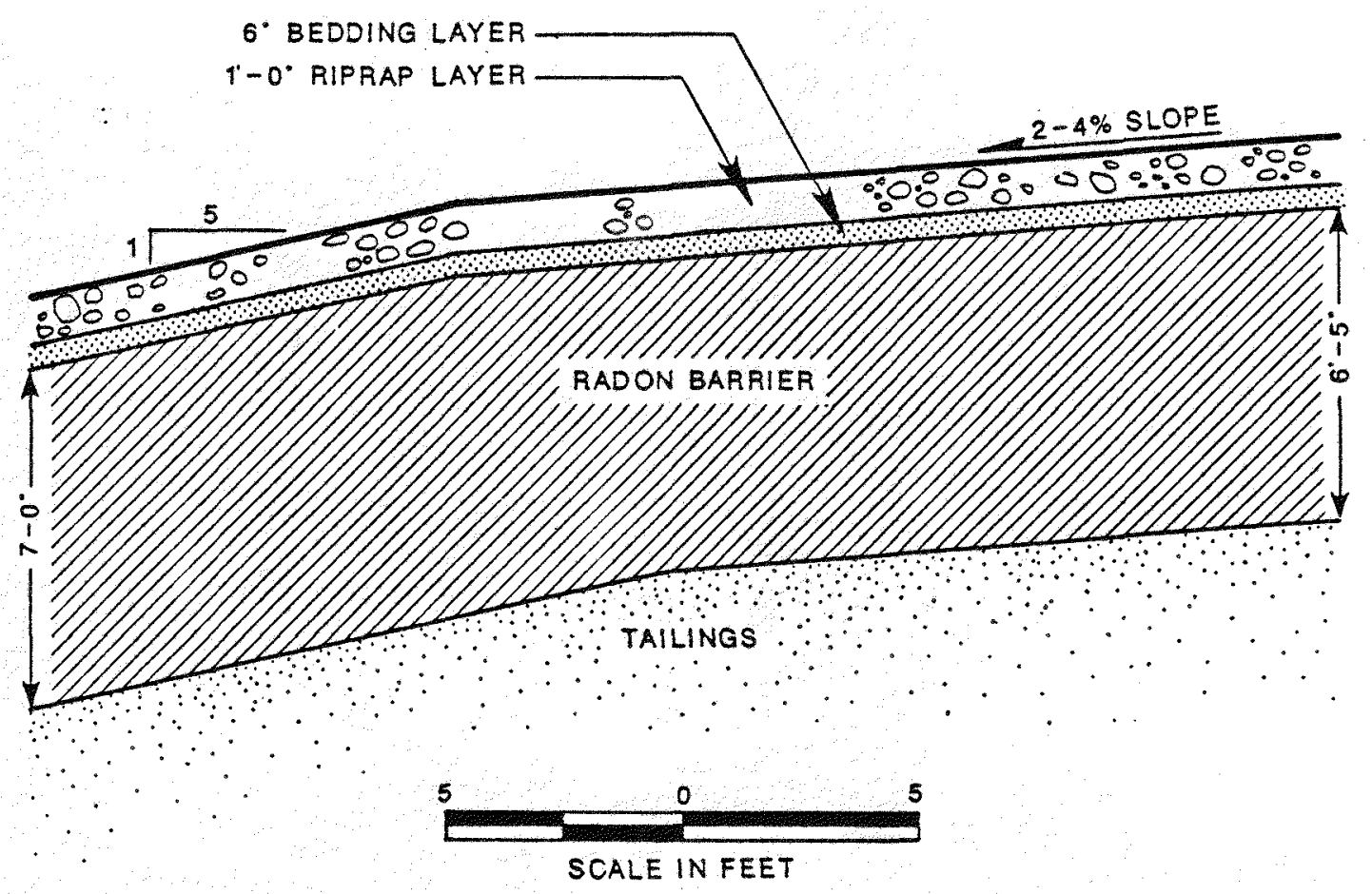

a) SHIPROCK, NEW MEXICO, DISPOSAL CELL

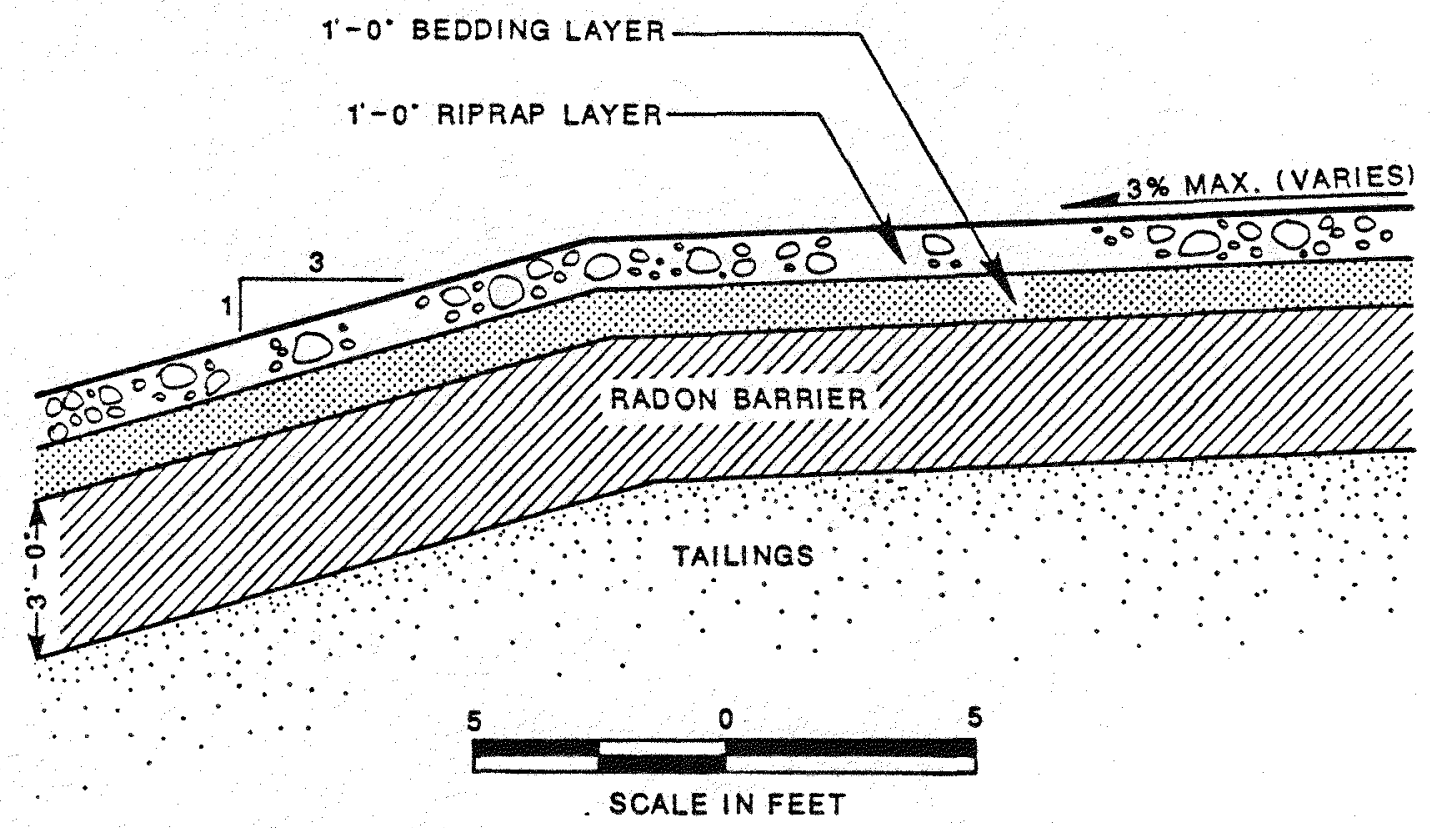

b) BURRELL, PENNSYLVANIA, DISPOSAL CELL

FIGURE 2.2

TYPICAL CROSS SECTIONS 


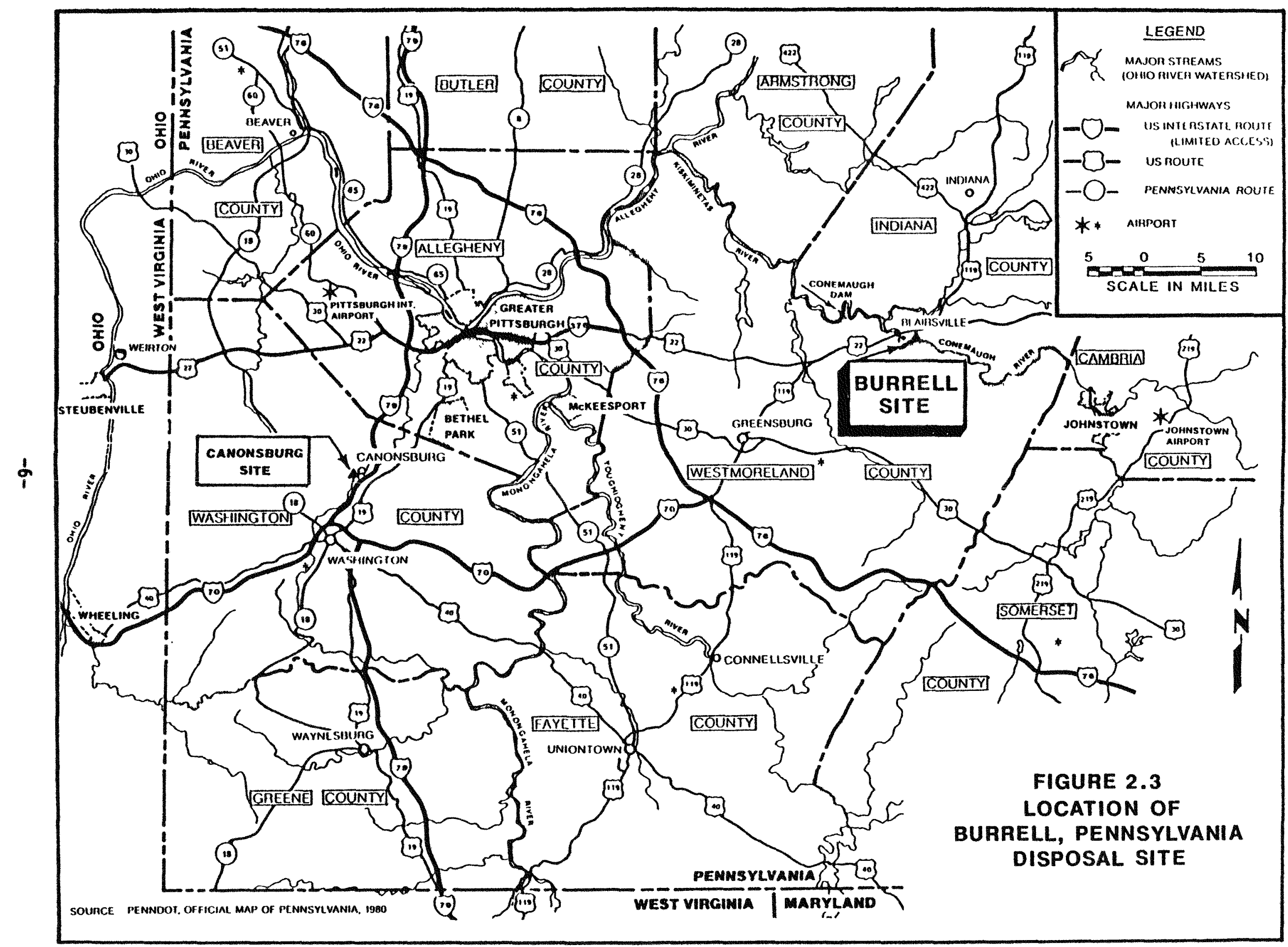


as cattail (Typha latifolia), bullrush (Scirpus spp.), and purple loosestrife (Lythrum salicaria) being common. The south and west edges of the pile are bordered by a perennial spring and its associated wetlands, which are part of the riparian habitat along the Conemaugh River. The wetlands along the spring are dominated by dense stands of cattai1, purple loosestrife, and bulirush that grow along the base of the pile (Appendix A, Photographic series 2).

The Burrell disposal cell was completed in July 1987 and covers six acres. A total of $54,000 \mathrm{cy}$ of contaminated materials were stabilized at this site. The cover system consists of a three-foot-thick compacted clay radon/infiltration barrier, one-foot-thick bedding layer, and a one-foot-thick rock erosion protection layer (Figure 2.2). The bedding layer is comprised of silty sand and some gravel. The rock size ranges from four to eight inches in diameter. 
$-8$ 


\subsection{FIELD METHODS AND RESULTS}

Field work took place at the Shiprock site on April 4 and 5, 1990, and at the Burrell site on July 19 and 20, 1990. Selected plants were excavated at these sites to determine rooting patterns in the cover systems. Hand shovels and trowels were used to excavate these plants. When lateral roots were found growing vertically downward into the compacted clay they were further excavated. In general, the excavations were approximately three feet in diameter at the surface and approximately 20 inches in diameter at the deepest part of the hole. The depth from the top of the rock cover to the bottom of the excavations was no more than 46 inches.

\subsection{SHIPROCK}

There is little diversity of plant species at the Shiprock site. The dominant plants are kochia and Russian thistle; saltcedar was the only perennial plant observed on the cell. The overall vegetation density was estimated to be less than five percent, with higher densities found on the north slope, west slope, and the western edge of the topslope.

All the plant species observed on the Shiprock cell have taproots; because saltcedar has the greatest potential to affect the cover, its rooting patterns in the cell were examined. The first saltcedar excavated was on the north slope; it was 7.5 feet high with a diameter of four inches at its base and was determined to be two years old (Appendix A, Photographic series 3 ). The 1arger roots generally penetrated down through the bedding layer until the compacted radon/ infiltration barrier was encountered. These roots then spread horizontally along the upper four inches of the radon/infiltration barrier. There were, however, some lateral roots angling downward into the radon/infiltration barrier.

The second saltcedar was excavated from the west slope of the pile. This saltcedar was the largest encountered on the pile. It was 15 feet high, six inches in diameter, and two years old. As with the first tree, there was a moderate cover of leaf litter around the tree (Appendix A, Photographic series 3). The filter material was moist but drier than that found on the north slope. The taproots extended vertically through the filter layer and then ran horizontally to slightly downward within the top four inches of the radon barrier. A few small lateral roots (approximately 0.2 inch in diameter) extended vertically into the radon/infiltration barrier and some were followed up to 28 inches into the barrier. These roots showed no signs of terminating at the bottom of the excavation, since the root diameter decreased little with depth. The rooting patterns of the saltcedar were similar to the patterns observed for two saltcedars excavated in 1988 at the Shiprock site (DOE, 1988).

Numerous rootlets from other $\mathrm{plants}$ were encountered at all levels in both of these excavations. Presumably these rootlets are from the numerous kochia and Russian thistle that were growing near the saltcedars. As with the saltcedars, the roots from these annuals have penetrated into the radon/infiltrataion barrier. 


\subsection{BURRELL}

The vegetation density on the Burrell disposal cell was estimated to be 20 percent, with higher densities found on the top, west, and northwest slopes. Thirty species of plants were found growing on the Burrell disposal cell (Table 3.1). Many of these are early successional species typical of recently disturbed 1and, while others are later successional species typical of bottomland riparian areas and wetlands along the nearby Conemaugh River. Some species are deeprooted, including woody species such as sycamore (Platanus occidentalis), treeof-heaven (Ailanthus altissima) and box-elder (Acer negundo), and herbaceous species such as Japanese knotweed (Polygonum cuspidatum).

The species with the most potential for adverse impacts to the cover system are the woody species, particularly the trees. Some of the herbaceous species that produce a large amount of biomass may also have an adverse impact. Hundreds of tree seedlings and a few small saplings made up principally of sycamore, tree-of-heaven, and box-elder are growing on the disposal cell. These trees are presently two to three years old and range from four inches to seven feet high.

The rooting patterns of Japanese knotweed, tree-of-heaven, white sweet clover, and giant mullein were examined by digging up individual plants. The excavation consisted of digging around the base of these plants to expose the major portion of the root system. Lateral roots that were found growing vertically downward into the compacted clay were further excavated.

The areas around and under the vegetation on the Burrell disposal cell were covered with a moderate layer of leaf litter. When the rock was removed from around the base of the vegetation, it was noted that the filter material was very moist and detritus feeders (isopods and crickets) were observed in the filter material.

The Japanese knotweed is one of the largest plants currently growing on the Burrell disposal cell (Appendix A, Photographic series 1). This species is very common on the pile and in the riparian zone south of the pile. The plant that was excavated was approximately 4.5 feet tall and had a fol $i$ age cover of approximately 30 square feet. The large roots grew down through the bedding 1 ayer and then grew horizontally at the interface of the bedding layer and compacted clay radon/infiltration barrier. The compacted clay of the barrier was excavated and the roots were found growing within the top four inches of the barrier. There were numerous root hairs found in the upper portion of the barrier and some small (0.2 inch in diameter) lateral roots angling downward into the barrier. The rooting pattern of this plant was very similar to the rooting patterns of the two saltcedars excavated on the Shiprock cell.

The tree-of-heaven is very common on the disposal cell and ranges from a few inches to three feet in height. One specimen next to the excavated Japanese knotweed was excavated. This tree was two years old, approximately 51 inches tall, and had a trunk diameter of one inch. The taproot extended through the bedding layer to the top of the radon/infiltration barrier, where it was starting to grow horizontally. There were a few lateral roots starting to grow into the barrier. 
Table 3.1 Plant species observed at the Burrell, Pennsylvania, disposal cel1 on JuTy 18 and 19,1990

\begin{tabular}{|c|c|c|}
\hline Common name & Scientific name & Relative abundance \\
\hline $\begin{array}{l}\text { Black locust } \\
\text { Box-elder } \\
\text { Bull thistle } \\
\text { Canada thistle } \\
\text { Catnip } \\
\text { Common plantain } \\
\text { Crown vetch } \\
\text { Dandel ion } \\
\text { Dogbane } \\
\text { Goldenrod } \\
\text { Giant mullein } \\
\text { Hop clover } \\
\text { Japanese knotweed } \\
\text { Jewelweed } \\
\text { Moth mullein } \\
\text { Mother wort } \\
\text { Ox-eye } \\
\text { Purple loosestrife } \\
\text { Quaking aspen } \\
\text { Queen Anne's lace } \\
\text { Red raspberry } \\
\text { Spotted joe-pye weed } \\
\text { Spotted knapweed } \\
\text { Sugar maple } \\
\text { Sycamore } \\
\text { Teasel } \\
\text { Tree-of-heaven } \\
\text { White sweet clover } \\
\text { Wild rose } \\
\text { Yellow sweet clover }\end{array}$ & $\begin{array}{l}\text { Robinia pseudo-acacia } \\
\text { Acer negundo } \\
\text { Cirsium vulgare } \\
\text { Cirsium arvense } \\
\text { Nepeta cataria } \\
\text { Plantago major } \\
\text { Coronilla varia } \\
\text { Taraxacum officinale } \\
\text { Apocynum spp. } \\
\text { Solidago spp. } \\
\text { Verbascum thapsus } \\
\text { Trifolium agrarium } \\
\text { Polygonum cuspidatum } \\
\text { Impatiens spp. } \\
\text { Verbascum blattaria } \\
\text { Leonurus cardiaca } \\
\text { Heliopsis helianthoides } \\
\text { Lythrum salicaria } \\
\text { Populus tremuloides } \\
\text { Daucus carota } \\
\text { Rubus idaeus } \\
\text { Eupatorium maculatum } \\
\text { Centaurea maculosa } \\
\text { Acer saccharum } \\
\text { Platanus occidentalis } \\
\text { Dipsacus sylvestrig } \\
\text { Ailanthus altissima } \\
\text { Melilotus alba } \\
\text { Rosa spp. } \\
\text { Melilotus officinalis }\end{array}$ & $\begin{array}{l}R \\
V C \\
R \\
R \\
C \\
R \\
S \\
R \\
R \\
V C \\
S \\
R \\
V C \\
R \\
R \\
S \\
R \\
S \\
R \\
S \\
S \\
R \\
R \\
R \\
V C \\
S \\
V C \\
V C \\
S \\
R\end{array}$ \\
\hline
\end{tabular}

\footnotetext{
${ }^{\circ} \mathrm{VC}$ indicates very common; hundreds of individuals.

$C$ indicates common; greater than 50 to 100 individuals.

$S$ indicates scattered; low numbers but found all over the pile.

$R$ indicates rare; less than a dozen individuals.
} 
One white sweet clover and a giant mullein were dug up from the same excavation on top of the cell. Both of these plants have fibrous root systems, rather than the taproot systems of most shrubs and trees. The white sweet clover was approximately three feet in height. The giant mullein's basal leaves were approximately one foot in height. In both cases the roots were well established within the filter layer but had not reached the radon/infiltration barrier. 


\subsection{DISCUSSION}

\subsection{ROOTING PATTERNS}

As stated in the introduction, this special study was designed, in part, to assess the rooting pattern of plants growing on rock-covered disposal cells. The information obtained from this study has provided insights into the factors that contribute to plant growth on the cells, along with some indication of the distribution of plant roots within the cover system. The major difference between the two sites is the extreme difference in available water in the form of rainfall; Burrell receives over seven times more precipitation than Shiprock. This has resulted in the Burrell disposal cell having a greater diversity of plant species (10 times more species than at Shiprock), more uniform distribution of vegetation, and a greater vegetative cover than at the Shiprock disposal cell.

Observations at Shiprock indicate that the aspect of a given location on the cell influences plant growth. Differences in the density of plant growth were noted on the slopes, with the slopes receiving more direct sun (southeast and southwest slopes) having noticeably less vegetation than the northwest and northeast slopes. The drainage characteristics of the topslope also influence plant growth. A relatively dense growth of annual plants was observed on the downslope edge of the topslope (especially at the western edge of the pile), which receives runoff from upslope areas.

No obvious differences in plant distribution by area were noted on the Burrell pile. Common species such as sycamore, tree-of-heaven, box-elder, and Japanese knotweed were evenly distributed over the pile. White sweet clover was the most common annual species and it was most common on the top of the cell.

However, despite the obvious differences, there was a similarity in the rooting patterns at both sites that can be attributed to the similarity in cover systems. Plants with relatively extensive root systems (saltcedar at Shiprock and Japanese knotweed at Burrell) had their roots similarly distributed within the covers at both sites. Both species grew through the bedding layer and then primarily horizontally in the top four inches of the compacted radon/infiltration barrier. The roots were almost totally embedded in the radon/infiltration barrier but had not penetrated into the barrier to any significant degree. One possible reason for this is the highly compacted nature of this layer. This layer was found to be very hard to dig in during the excavations and may be resistant to root penetration. The large roots may find the upper four inches of the radon barrier favorable in that ionic exchange of nutrients within the root hairs may be enhanced in the clay (Raven, 1986). However, the bedding 1 ayer provides a favorable rooting medium for plant growth and plants do not need to exploit the less favorable conditions found deeper in the radon/infiltration barrier. Conditions for plant growth are enhanced by the rock cover layer, which acts as a mulch and reduces evaporation from the filter layer. The filter layer itself serves as a rooting medium. The conservation of water by the rock layer is more significant at the dry Shiprock site but may increase in importance at the Burrell site during drought years. 


\subsection{IMPACTS ANALYSIS}

Another aspect of this study was to assess possible impacts of vegetation growing on the rock-covered cells and identify measures, if any, that could control vegetation. At least three types of negative impacts are possible from vegetation growing on the rock covers. They are 1) enhancement of the transport of hazardous constituents out of the cell, 2) physical damage to a cell, and 3 ) successional processes. These three impacts do not work independently. For example, ecological succession could enhance environmental conditions for deeprooted species not previously on the cell to invade and provide a possible pathway for hazardous constituent transport to the environment.

Studies have shown that plants may provide a pathway for the release of radionuclides and other hazardous constituents from uranium mill tailings (Nylan, 1989; Dave et a1., 1985; Rumble, 1982; Dreesen and Marple, 1979). Dreesen and Marple (1979) determined that vegetation accumulated molybdenum (Mo), selenium $(\mathrm{Se})$, uranium (U), and radium-226 (Ra-226). The Mo and Se concentrations were bioaccumulated to levels that could be detrimental to wildlife. Dave et al. (1985) found detectable levels of $\mathrm{Ra}-226$ and 1 lead-210 (Pb-210) in vegetation growing on tailings piles. Rumble (1982) measured $U$, thorium (Th), and $\mathrm{Pb}$ in vegetation growing on tailings piles in South Dakota. In the above referenced studies, the roots had penetrated the tailings. In a study by Morris and Fraley (1989), it was determined that radon-222 (Rn-222) emanation from study plots with plants growing in soil over tailings was enhanced over that of unvegetated plots. One study plot had a soil layer and clay cap over the tailings and another was just soil over the tailings. Radon-222 emanation from the plot with the clay cap was six to 18 times greater than from the plot without the clay. The roots had not reached the tailings and only six percent of the root biomass was in the clay cap. It was hypothesized that the clay trapped $R n-222$ and that the plant roots were transpiring $\mathrm{Rn}-222$ laden water out of the clay. Radon-222 emanation from the clay cap plot was frequently above the EPA standard of 20 picocuries per square meter per second.

Data regarding biological transport of radionuclides were not collected during this special study nor have any other studies regarding this topic been conducted for the UMTRA Project. However, the information cited in the above studies indicates that plant transport of radionuclides and other hazardous constituents may be a problem for the UMTRA Project. Plant roots have the potential for growing deeper into the radon/infiltration barrier and even into the tailings at the two sites under study. Nyhan (1989) determined that plant roots can deplete water from the clay layer and result in shrinkage and cracks, which enable roots to move deeper into the clay layer seeking water. Over the long term, this process could affect the integrity of the radon/infiltration barrier and promote the direct transport of hazardous constituents from the tailings or result in increased emanation of $\mathrm{Rn}-222$, as reported by Morris and Fraley (1989).

Another indication from this study that roots may penetrate deeper into the radon/infiltration barrier is that the large, deep-rooted species excavated at both sites had most of their roots in the top four inches of the barrier. The Vegetative Cover Special Study (DOE, 1988) indicated that in 1988, Russian thistle and kochia roots had not penetrated the radon/infiltration barrier at the Shiprock disposal cell. Observations during this study suggest that rootlets from one or both of these species had penetrated to a11 levels excavated (up to 28 inches into the radon barrier). Limited rooting depth information for these 
species indicates that Russian thistle can root up to 26 inches deep and kochia up to 78 inches (Foxx et al., 1984).

Vegetation may also cause physical damage to a disposal cell. This finding is consistent with that by Beedlow (1984), who determined that rock covers provide favorable conditions for deep-rooted trees, shrubs, and forbs and that very little grass, which is typically shallow-rooted, grows on these cells. Some of the deep-rooted tree species growing on the Burrell disposal cell would likely send roots deep into the radon/infiltration barrier and, eventually, the tailings to support their above-ground biomass. These trees could then become uprooted and damage the cell. Large tree species are not presently growing on the Shiprock pile. However, cottonwood trees grow along the nearby San Juan River and could eventually invade the Shiprock cell.

The third possible impact relates to long-term effects of ecological succession. As plant species invade the disposal cell, soil conditions improve and other species will become established. In the western United States, Beedlow (1984) determined that weedy species such as Russian thistle and kochia were the common pioneer plants on rock covers and that perennial plants will become established slowly. Russian thistle and kochia have been the common species growing on the Shiprock cell for the past three growing seasons (1988 through 1990); the primary perennial species observed is saltcedar. It can be expected that other perennial species such as desert shrub and riparian species that grow near the cell will become established. Some of these, such as greasewood and rabbitbrush (Chrysothamnus), are deep-rooted species that could lead to the transport of hazardous constituents into the environment.

The Burrell site was completed in July 1987, and vegetation has grown on the rock cover for three growing seasons (1988 through 1990). During a site inspection in August 1988, very sparse vegetative growth was observed (Appendix $A$, Photographic series 4) (DOE, 1989). White sweet clover was the most common species observed; widely scattered Japanese knotweed and tree-of-heaven were al so observed. The November 1989 site inspection showed that vegetation growing on the pile had increased (Appendix A, Photographic series 4) (DOE, 1990). Observations during this special study documented in a high degree of plant invasion on the pile in three years. A mixture of pioneer and mid to late successional species have invaded this cell, essentially all at the same time (Table 3.1 lists the species observed in 1990), indicating that the soil conditions at the site are favorable to many different species. This relatively high plant species diversity and plant density increases the possibility of plant roots transporting hazardous constituents out of the cell or damaging the cell.

\subsection{VEGETATION CONTROL}

It is apparent from this and other studies that the cover components of disposal cells interact as a system in terms of regulating soil moisture, plant germination, and root growing patterns. While it is clear that rock covers can reduce or eliminate erosion of the lower layers of the cover system and the stabilized contaminated material, this same cover may create problems in terms of plant root biointrusion. Measures may need to be taken at the two sites to control biointrusion. An overriding consideration for any possible plant control 
measures at these sites is the possible release of $\mathrm{Rn}-222$ by vegetation (Morris and Fraley, 1989). A comparison of the cover system used by Morris and Fraley (1989) with the Shiprock and Burrell covers shows that the UMTRA Project site covers are much thicker than those of Morris and Fraley (1989) (Figure 4.1). The major difference is the clay layer, which was approximately one foot thick in Morris and Fraley's (1989) study and ranged from three (Burrell cell) to seven feet thick (Shiprock cell) at the UMTRA Project sites. Conversely, the rooting layer above the clay layer was thicker in the Morris and Fraley study (1.75 feet) than on the Burrell (one-foot-thick bedding layer) and Shiprock (six-inch-thick bedding layer) cells. Morris and Fraley's (1989) study indicates that it may take a period of years before enhanced Rn-222 emanation will occur. Hinton and Whicker (1985) conducted the initial study on $\mathrm{Rn}-222$ emanation from the same study plots used by Morris and Fraley. Hinton and Whicker (1985) observed no difference in Rn-222 emanation from covers with and without clay. Morris and Fraley (1989) conducted their study two years after Hinton and Whicker and observed enhanced Rn-222 emanation over the clay-capped plot. This could be due to a combination of increased root penetration into the clay or $R n-222$ laden water rising up through the clay. This indicates, as Morris and Fraley (1988) stated, that deeper burial of waste material, as at the UMTRA Project sites, may not be a solution to the problem of vegetation-caused transport of $R n-222$, especially given the deep-rooting nature of some of the plants growing at the sites.

As work continues on the UMTRA Project, more disposal cells with rock covers will be constructed. To date, the Shiprock, Burrell, Green River (Utah), Clive (Salt Lake City, Utah, disposal site), and Tuba City (Arizona) disposal cells have rock covers and seven additional sites are slated for rock covers (Table 4.1). As a result of the NRC (1990) position on rock erosion protection layers, the cover design for the Grand Junction and Naturita, Colorado, disposal cells will likely be changed from a vegetated to a rock cover. This same change could take place at other UMTRA Project sites in the arid/semiarid west (e.g., Gunnison, Maybell, and Slick Rock, Colorado, sites). Potential problems with vegetation transporting hazardous constituents to the environment would apply to both vegetative and rock cover systems.

The use of biointrusion layers has been studied as a means for preventing root intrusion into contaminated material. According to Nyhan (1989) "most of these approaches rely on physical or chemical barriers to prevent plant roots and/or burrowing animals from accessing the waste. Examples of physical barrier systems include natural geologic materials such as rocks or artificial barrier material such as hypalon sheeting or asphalt emulsions. Chemical barrier systems include the use of biotoxins." Gee et al. (1989) found that a 2.7-inch-thick asphalt layer over tailings at the Grand Junction, Colorado, tailings site limited radon flux to well below the EPA standards over a seven-year period. No data regarding root penetration into the asphalt layer were provided. However, results of studies carried out for Los Alamos National Laboratories in New Mexico indicate that asphalt, hypalon, and concrete have a field life of no more than 25 years (Pertusa, 1980 as cited in Nyhan, 1989). Cobble or rock/cobble biobarriers began to fail after five years, while clay barriers dried out and formed cracks that were channels for plant roots (Nyhan, 1989). The effective life of chemical biobarriers varied from 68 to 104 years at a soil temperature of 12 degrees centigrade (Van Voris et al., 1988). The effectiveness of biobarriers is still under study, but at this time it appears questionable that these systems will perform for the long period of time required for the UMTRA Project. 


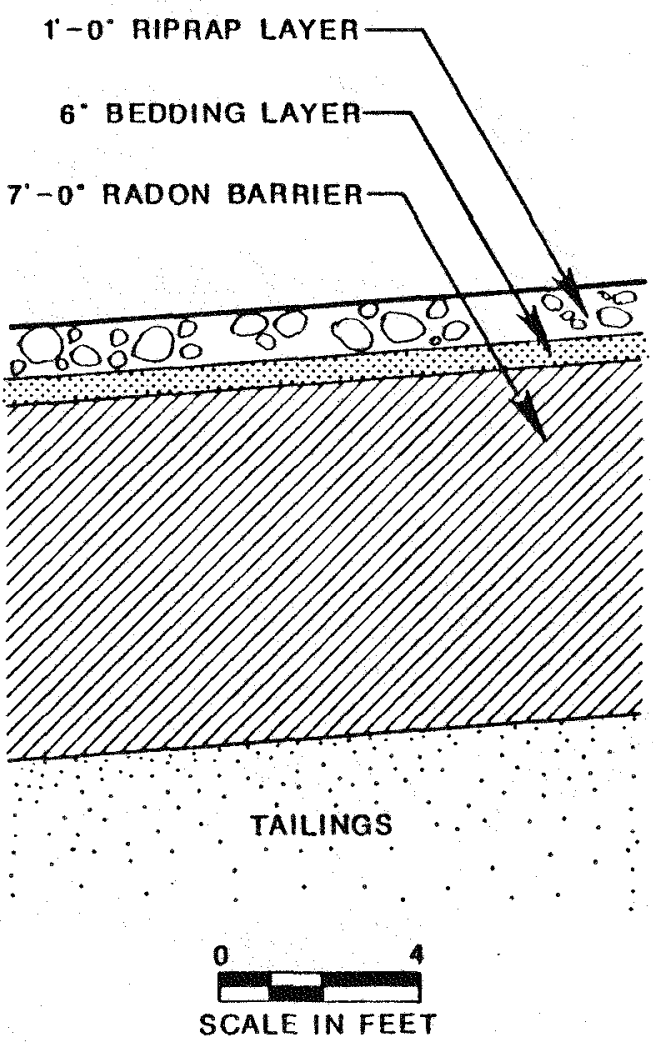

a) SHIPROCK, NEW MEXICO, DISPOSAL CELL

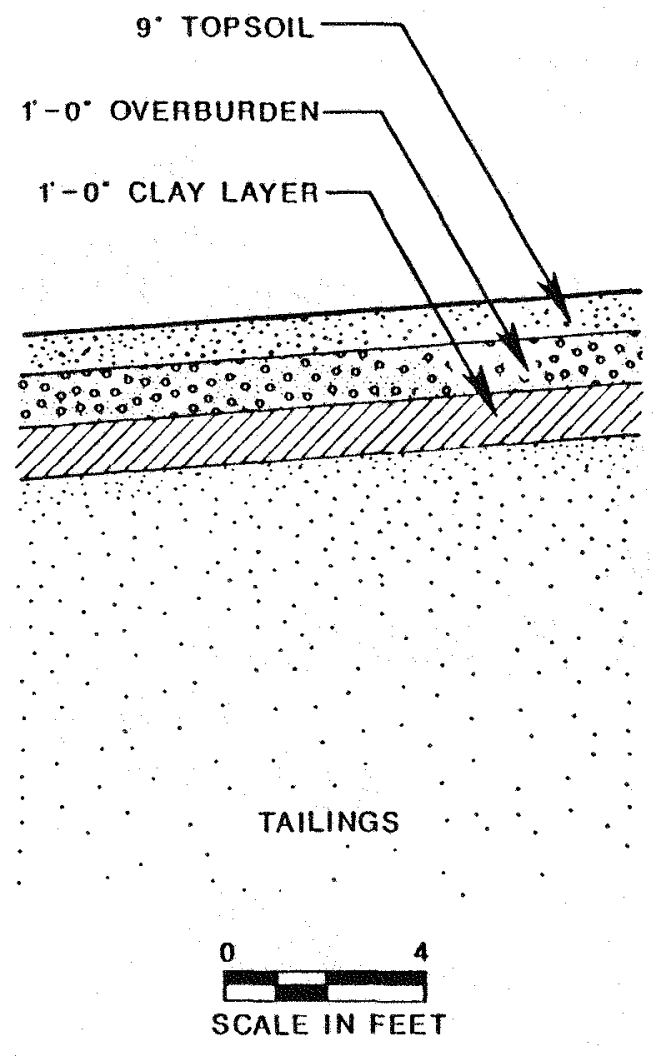

b) MORRIS AND FRALEY (1989) COVER SYSTEM

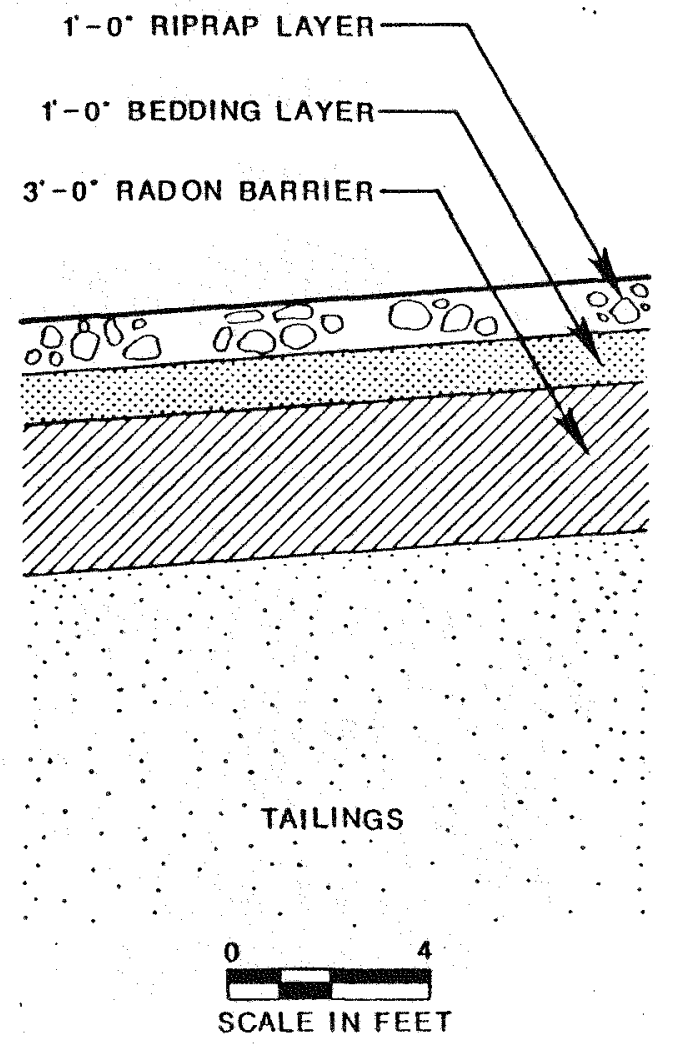

c) BURRELL, PENNSYLVANIA, DISPOSAL CELL

FIGURE 4.1

TYPICAL CROSS SECTIONS

FOR MORRIS AND FRALEY (1989) AND UMTRA PROJECT DISPOSAL CELLS 
Table 4.1 Existing and proposed erosion protection layers for UMTRA Project disposal cells

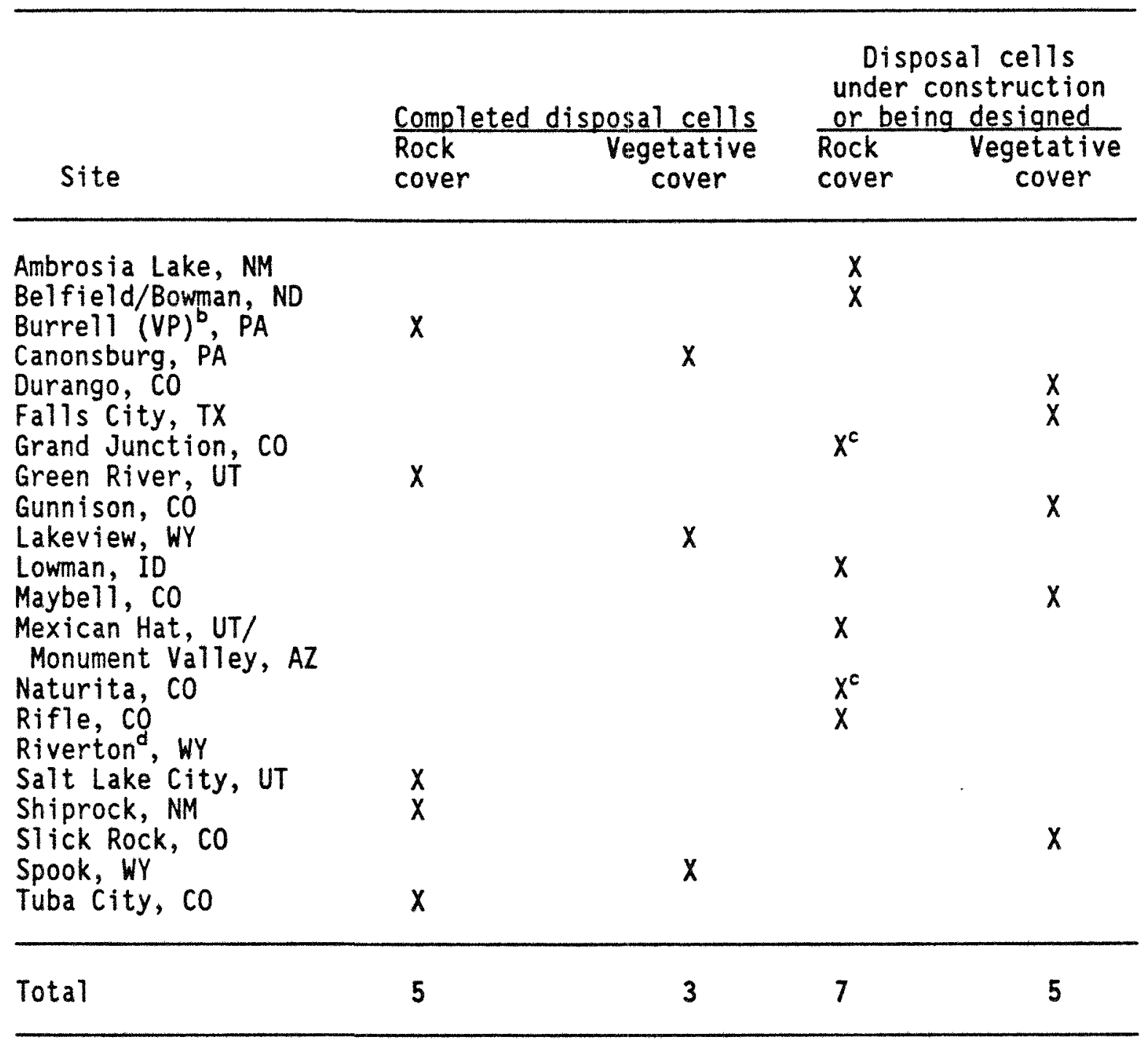

Table refers to erosion protection on topslopes of disposal cells. VP refers to vicinity property.

'Originally proposed to have vegetative cover but now is likely to have rock cover.

dNot stabilized in an UMTRA Project disposal cell. 
Another possible measure for rock covered piles is to deepen the rock layer to such an extent as to prevent plant growth. There are several probler: with this approach, including 1) the depth of rock needed to prevent plant growth has not been determined, 2) a deep rock cover may increase moisture within the tailings to such an extent as to jeopardize the integrity of the cell (Beedlow, 1984) and make it impossible to comply with the EPA groundwater protection standards (40 CFR 192.2(a)(2)-(3)), and 3) a significant increase in the depth of rock could lead to a significant increase in the cost of the disposal cell. Before this measure can be recommended, the three problem areas listed above need to be resolved.

Plant growth on future rock-covered cells may be 1 imited by creating a coarser bedding layer than used at the Shiprock and Burrell cells. Such a layer would shed water more quickly than finer layers (Abt, 1989) and would be less suitable as a rooting medium. This measure will be implemented at the Mexican Hat/ Monument Valley disposal cell. However, as pointed out earlier, the cover acts as a system and changing one component of the cover is likely to change plant response in the other components. For example, plants may initially take root in the layer below the bedding layer (i.e., radon/infiltration barrier or frost protection layer) rather than the bedding layer. If the radon/infiltration barrier is directly below the bedding layer, then use of the coarse bedding layer could actually enhance rather than deter plant root penetration of the radon/ infiltration barrier. In addition, fine-grained material may begin to accumulate in the bedding layer over time, which would improve its capacity to support rooting plants. As part of the expanded biointrusion study outlined below, the rooting behavior of plants growing on disposal cells with a coarse-grained bedding layer will be monitored.

A deep soil layer could be used over the radon/infiltration barrier to limit plant root penetration into the barrier. Use of this type of layer with a rock cover would not guarantee that plant roots will not reach the radon/infiltration barrier. As this and other studies have demonstrated, the use of rock covers promotes the establishment of deep-rooted plants. Species such as rabbitbrush and big sagebrush (Artemisia tridentata) are deep rooted (maximum reported depths of 15 and 30 feet, respectively (Foxx et al., 1984)) and occur near many of the UMTRA Project sites. Site characterization studies at the disposal site for the Grand Junction tailings identified plant roots 30 feet beneath the surface (presumabiy greasewood). In addition, Morris and Fraley's (1989) study showed that very little root biomass in the clay cap was required to result in enhanced $\mathrm{Rn}-222$ emanation. As with other cover design modifications, plant root growth in a cover with a thick soil layer would need to be monitored.

Another approach to controlling deep-rooted plant species is to have a vegetative cover that can support more shallow-rooted plant species such as grass and herbs. This approach has been implemented at and is planned for several UMTRA Project sites (see Table 4.1). The Vegetative Covers Special Study (DOE, 1988) demonstrated that a vegetative cover of drought-tolerant species could be established on the topslopes of disposal cells. The use of a rock mulch can enhance the water-holding capacity of the soil and inhibit wind erosion. The Vegetative Covers Special Study proposed the use of a cobble/rock biointrusion barrier, which, as pointed out above, may not be suitable over the long-term life of the UMTRA Project disposal cells. As with the other cover systems and modifications addressed in this report, the rooting behavior and potential $\mathrm{Rn}-222$ emanation would need to be monitored on vegetative covers. In addition, as mentioned in the introduction, the use of vegetative covers is being questioned by the NRC (1990) as not providing sufficient protection against erosion. 
Vegetation control on an UMTRA Project disposal cell could take the form of mechanical or chemical elimination of plants. However, the use of mechanical methods (hoéing, disking, and cutting) to control vegetation would not be appropriate because of the large rock on the top of the disposal cells. Manual hoeing and cutting would be ineffective because of the problem of trying to hoe or cut between the rocks. The remaining portions of the plant stems and roots could produce new plants through sprouting.

The use of fire for plant control has the same disadvantages as the mechanical methods in that the lower stems and roots left intact could re-emerge. In addition, the residue left after the burning could actually improve the soil for subsequently invading vegetation.

Chemical methods (herbicides) can be direct or pre-emergence. Pre-emergence herbicides work primarily by attaching to clay particles within the soil. The large rock on the surface and the relatively clean sand (no clay or silt) used for the filter material of UMTRA Project disposal cells do not provide the appropriate substrate for the use of this type of herbicide. The herbicide would dry on the rock or flush through the filter material of the cover system.

The most effective way to control vegetation is the use of directly applied herbicides. Herbicides should be applied to young plants that are not under stress (i.e., not in a drought condition) and that are growing well. This allows the active ingredient in the herbicide to be absorbed by the plant more efficiently. The major problem with this approach is that herbicides may have to be applied yearly, and in order to maintain complete control of invading vegetation, the herbicides should be applied two to three times a year.

The selective removal of deep-rooted plants would have to be evaluated on a site-specific basis considering the thickness of each component of the cover system and the ecological setting of the site. For example, selective removal of plants may be feasible at the disposal cells with relatively few deep-rooting plants, but would not be applicable to the Burrell site where literally hundreds of woody plants grow all over the pile.

\section{Conclusion}

In conclusion, it does not appear that there are design options available that can provide the assurance necessary that plant roots will not transport hazardous constituents into the environment for the 200- to 1000-year design 1 ife of UMTRA Project disposal cells. This applies to existing as well as proposed disposal cells. Therefore, it is recommended that a vegetation control management plan be implemented for the UMTRA Project disposal cells as part of custodial maintenance. This would likely combine mechanical and chemical control measures. If possible, the formulation of such a management plan should be prepared following the completion of the first year of the proposed extension to the biointrusion special study. The results of such a study could affect the type of management required. For example, if it is determined that vegetation at the Burrell site is transporting Rn-222 to the environment or if the roots are penetrating the radon/infiltration barrier to a significant degree, then an immediate vegetation control program would likely be required. Conversely, if no such effects were observed, then vegetation control at the Burrell site could probably be postponed for two or three years. 
4.4 FUTURE STUDIES

An extension of the biointrusion study will be proposed to address the following issues.

1. Determine $R n-222$ emanation from vegetation growing on remediated and unremediated UMTRA Project disposal cells.

2. Monitor vegetation growing on remediated UMTRA Project disposal cells, including:

a. Inventory plant species growing on the cells.

b. Measure vegetation density and relative abundance of plant species growing on the cells.

c. Monitor rooting patterns of selected plants in the covers of completed UMTRA Project disposal cells.

3. Monitor success of vegetation management program. 
$-22-$ 


\subsection{SUMMARY}

This special study has demonstrated that roots of plants growing on the Shiprock and Burrell UMTRA Project disposal cells are penetrating the radon/ infiltration barrier. This growth was mostly restricted to the top four inches of the barrier. Information from other studies has demonstrated that there is a potential for plant roots to transport radon and other hazardous constituents to the environment. At present, it does not appear that engineered design changes to the UMTRA Project disposal cells can ensure that plant roots will not transport such constituents to the environment for the 200- to 1000-year design life of the disposal cells. In addition, changing the covers at remediated sites to control vegetation is not a viable alternative. A management plan for monitoring and controlling vegetation at remediated UMTRA Project sites needs to be developed. This plan should be flexible to allow for site-specific implementation. Vegetation management would likely become part of custodial maintenance under the long-term surveillance and maintenance activities.

Information collected during this and other studies has shown that the UMTRA Project disposal cell covers are dynamic systems in terms of plant growth, rooting patterns, and moisture content. An evaluation of this system in terms of the impact and control of vegetation growth will require a multidisciplinary approach including biologists, engineers, and health physicists and will be proposed in a special study. Information gained from such a study will benefit the UMTRA Project as well as other projects addressing the disposal of hazardous and radioactive wastes. 
$-24$ 


\section{REFERENCES}

Abt et al. (S. R. Abt, K. M. High, D. M. Gongloff, and R. D. McDanie1), 1989. "Radon Barrier Erosion and Bedding Drainage Criteria for UMTRA Sites," prepared for Jacobs Engineering Group, Inc., Albuquerque, New Mexico.

Beedlow, P. A., 1984. "Revegetation and Rock Cover for Stabilization of Inactive Uranium Mill Tailings Disposal Sites: Final Report, "DOE/UMT-0217, Pacific Northwest Laboratory, Richland, Washington.

DOE (U.S. Department of Energy), 1990. Post-Stabilization Inspection of Burrell Uranium Mill Tailings Vicinity Property Burrell. Pennsylvania, UMTRA-DOE/AL-350201.0000, DOE UMTRA Project Office, Albuquerque Operations Office, Albuquerque, New Mexico.

DOE (U.S. Department of Energy), 1989. Post-Stabilization Inspection of Burrell Uranium Mill Tailings Vicinity Property Burrell, Pennsylvania, UMTRA-DOE/AL-350201.000, DOE UMTRA Project Office, Albuquerque Operations Office, Albuquerque, New Mexico

DOE (U.S. Department of Energy), 1988. Vegetative Covers Special Study, UMTRADOE/AL-400642.0000, DOE UMI, DOE UMTRA Project Office, Albuquerque Operations office, Albuquerque, New Mexico.

DOE (U.S. Department of Energy), 1985. Technical Summary of the UMTRA Project Technology Development Program (1990-1984), UMTRA-DOE/AL-200125.0000, DOE UMTRA Project Office, Albuquerque Operations Office, Albuquerque, New Mexico, p. 122.

DOE (U.S. Department of Energy), 1984. Environmental Assessment of Remedial Action at the Shiprock Uranium Mill Tailings Site, Shiprock, New Mexico, Volume 1, Text, UMTRA-DOE/AL, DOE UMTRA Project Office, Albuquerque Operations Office, Albuquerque, New Mexico.

DOE (U.S. Department of Energy), 1983. Final Environmental Impact Statement, Remedial Action at the Former Vitro Rare Metals Plant Site at Canonsburg, Washington County, Pennsylvania, UMTRA-DOE/EIS-0096-F, DOE UMTRA Project Office, Albuquerque Operations Office, Albuquerque, New Mexico.

Dave et al. (N. K. Dave, N. R. Cloutier, and T. P. Lim), 1985. "Radionuclide Levels in Vegetation Growing on Uranium Tailings, Elliot Lake, Ontario," in Seventh Symposium on Management of Uranium Mill Tailings, Low-Level Waste and Hazardous Waste, Colorado State University, Fort Collins, Colorado.

Dreesen, D. R., and M. L. Marple, 1979. "Uptake of Trace Elements and Radionuclides from Uranium Mill Tailings by Four-Wing Saltbush (Atriplex cenescens) and Alkali Sacaton (Sporobolus airoides)," in Symposium on Uranium Mill Tailings Management, Fort Coll ins, Colorado.

Foxx et al. (T. S. Foxx, G. D. Tierney, and J. M. Williams), 1984. Rooting Depths of Plants on Low-Level Waste Disposal Sites, LA-10253-MS, Los Al amos National Laboratory, Los Alamos, New Mexico. 
Gee et al. (G. W. Gee, M. D. Campbell, H. D. Freeman, and J. F. Cline), 1989. "Assessment of Cover Systems at the Grand Junction, Colorado, Uranium Mill Tailings Pile: 1987 Field Measurements," PNL-6762, Pacific Northwest Laboratory, Richland, Washington.

Hinton, T. G., and F. W. Whicker, 1985. "A Field Experiment on Rn Flux from Reclaimed Uranium Mill Tailings," in Health Physics, Volume 48, pp. 421-427.

Morris, R. C., and L. Fraley, Jr., 1989. "Effects of Vegetation, A Clay Cap and Environmental Variables on Rn-222 Fluence Rate from Reclaimed Mill Tailings," in Health Physics, Volume 56, pp. 431-440.

NRC (U.S. Nuclear Regulatory Commission), 1990. "Final Staff Technical Position--Design of Erosion Protection Covers for Stabilization of Uranium Mill Tailings Sites," Denver, Colorado.

Nyhan, J. W., 1989. "Development of Technology for the Long-Term Stabilization and Closure of Shallow Land Burial Sites in Semiarid Environments," LA11283-MS, Los Alamos National Laboratory, Los Alamos, New Mexico.

Pertusa, M., 1980. "Materials to Line or to Cap Disposal Pits for Low-Level Radioactive Wastes," Geotechnical Engineering Report GE80-1, University of Texas, Austin, Texas.

Rumble, M., 1982. "Biota of Uranium Mill Tailings Near the Black Hills," Proceedings of the Annual Conference of Western Association of Fish and Wildlife Agencies, Las Vegas, Nevada.

Van Voris et al. (P. Van Voris, D. A. Cataldo, C. E. Cowman, N. R. Gordon, J. F. Cline, F. G. Burton, and W. E. Skeins), 1988. "Long-Term Controlled Release of Herbicides," ACS Symposium Series 371, Pesticide Formulations, Innovations, and Developments, American Chemical Society, Washington, D.C. 
APPENDIX A

PHOTOGRAPHIC SERIES 
PHOTOGRAPHIC SERIES 1

BURRELL DISPOSAL CELL, JULY 19, 1990 


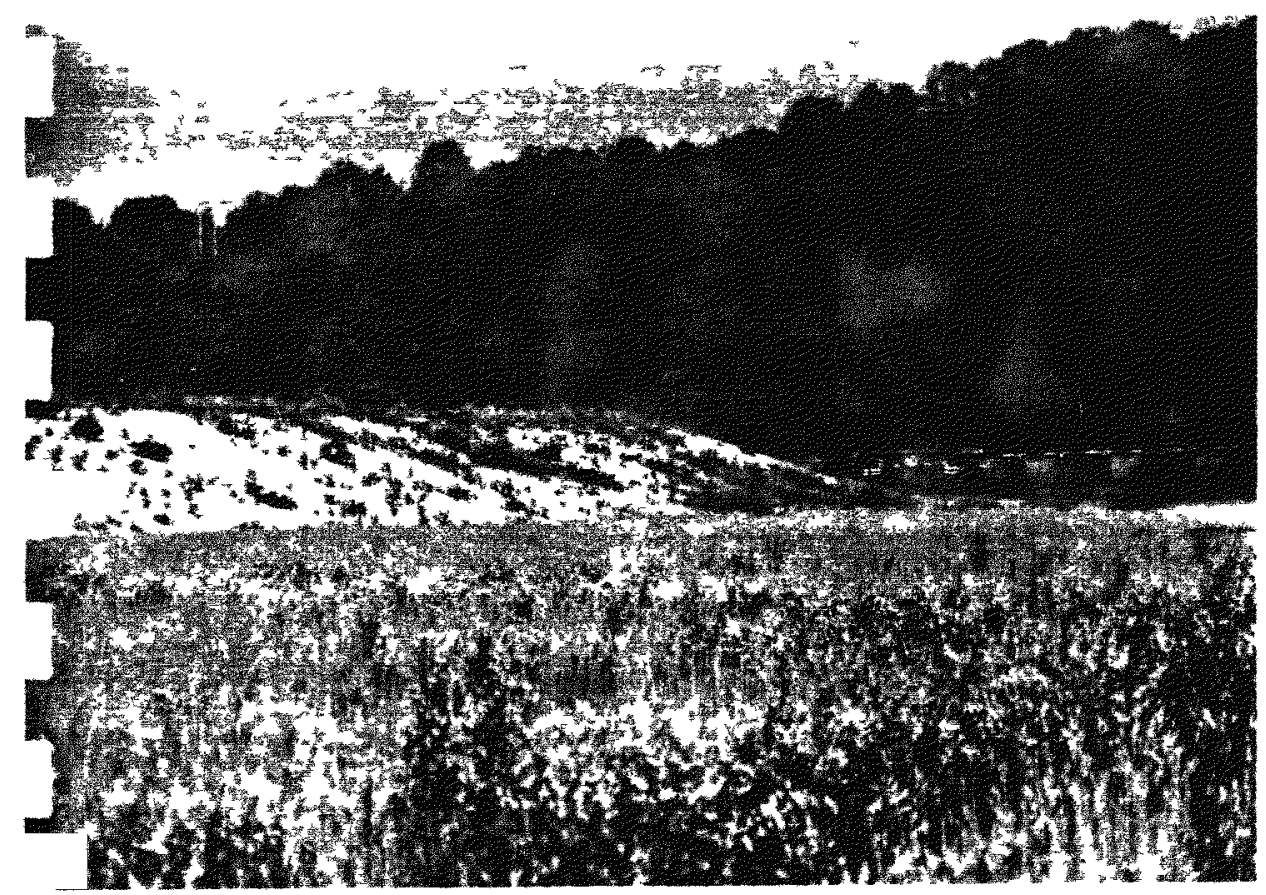

Burrell disposal cell (left middle of picture). Revegetated field in foreground.

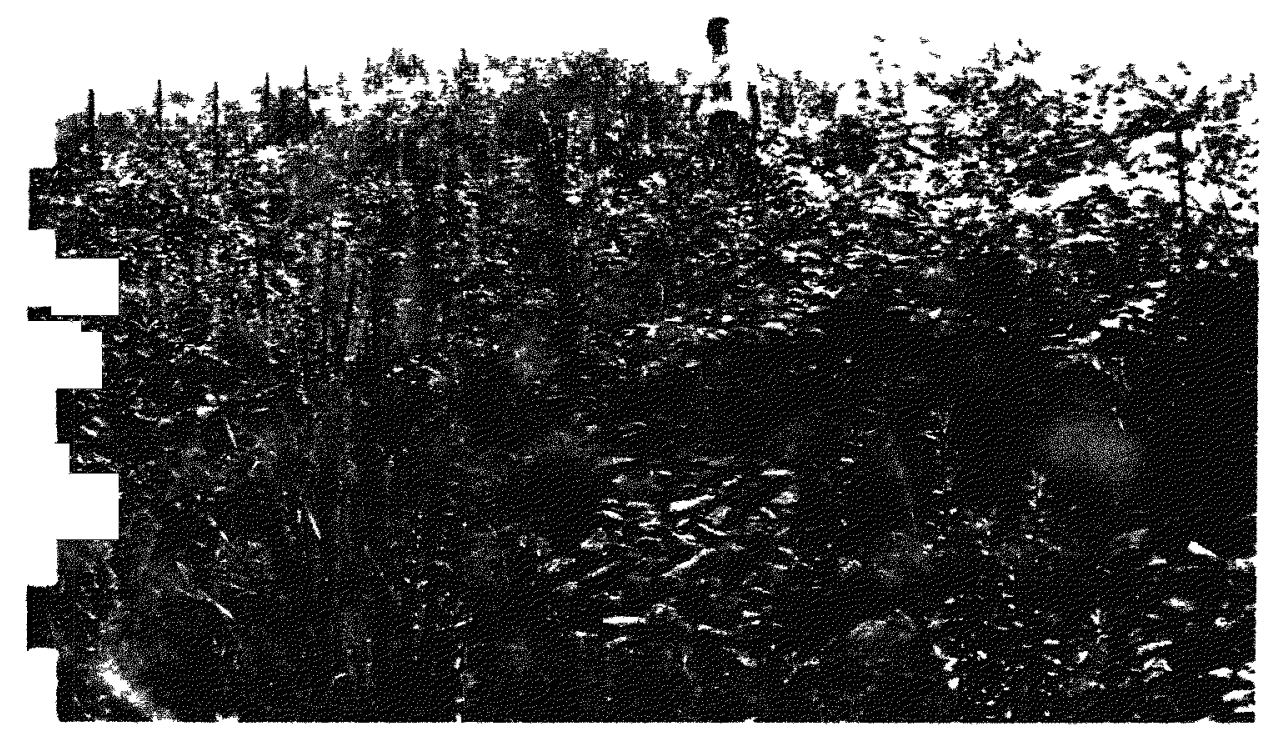

Northwest side of Burrell disposal cell from bottom of cell. Cattail in foreground; Japanese knotweed, white-sweet clover, and other species in background.

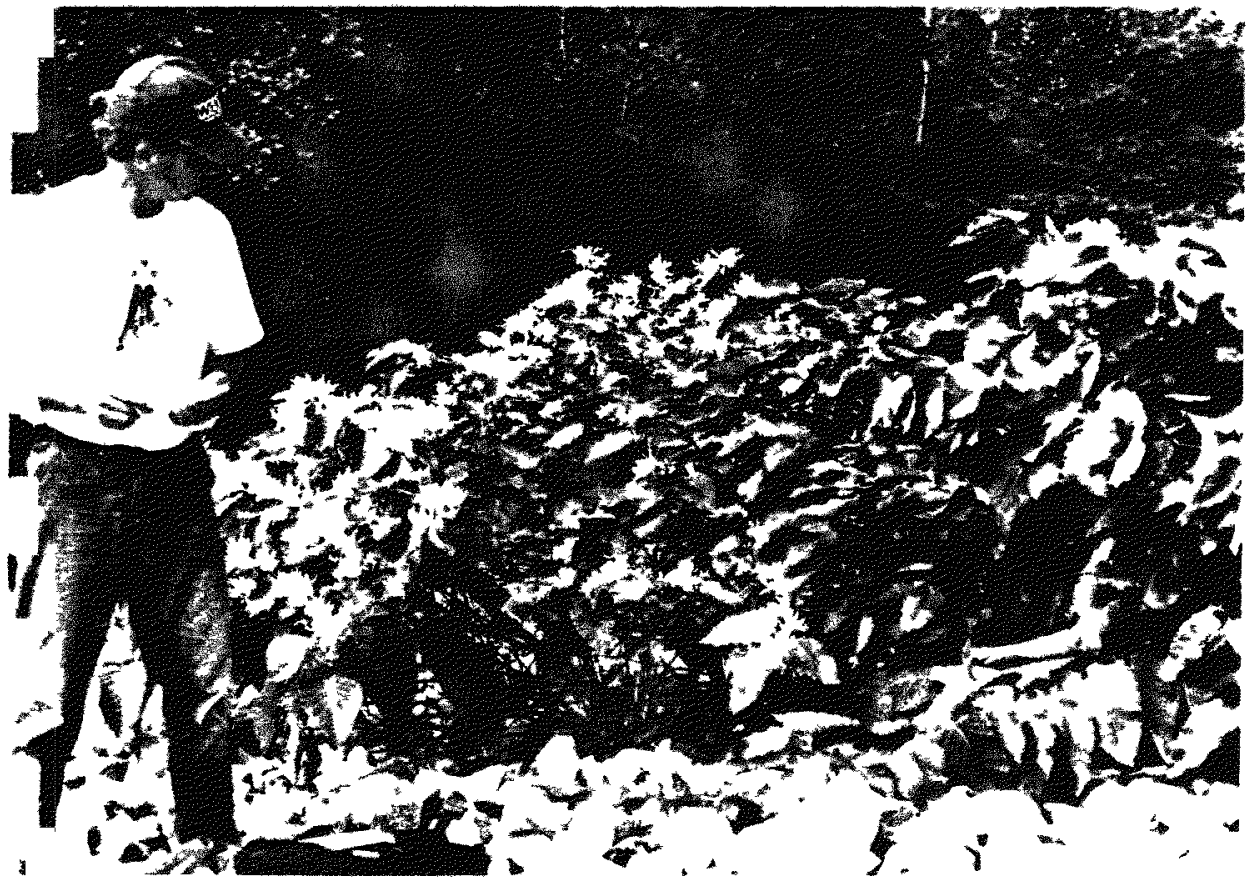

South facing slope of Burrell cell. Japanese knotweed that was excavated. 
PHOTOGRAPHIC SERIES 2

BURRELL DISPOSAL CELL WETLANDS, JULY 19, 1990 


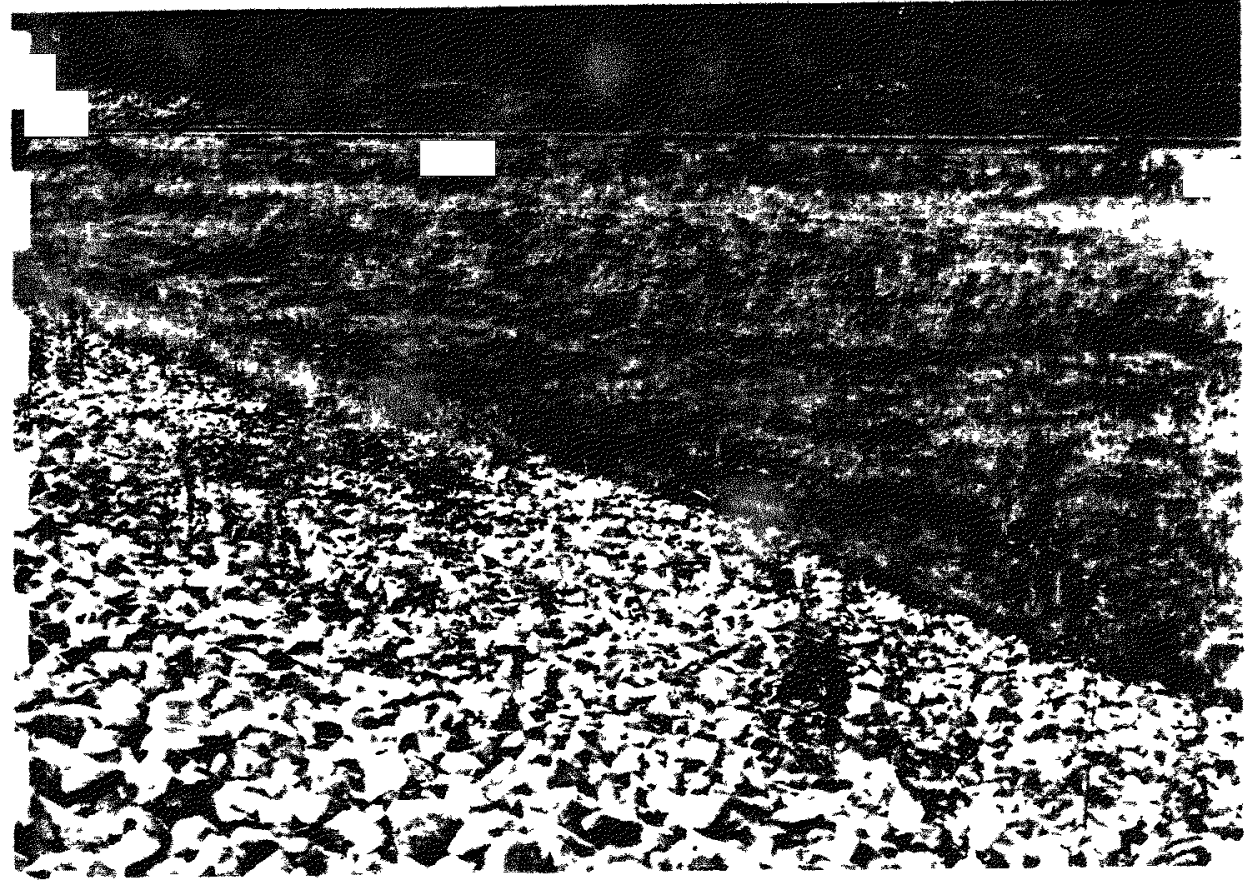

Ponded water and wetlands developing along northern border of Burrell cell.

Wetlands developing along northern border of Burrell cell.

Wetlands along southern border of Burrell cell. 


\section{PHOTOGRAPHIC SERIES 3}

SHIPROCK DISPOSAL CELL, APRIL 4, 1990 

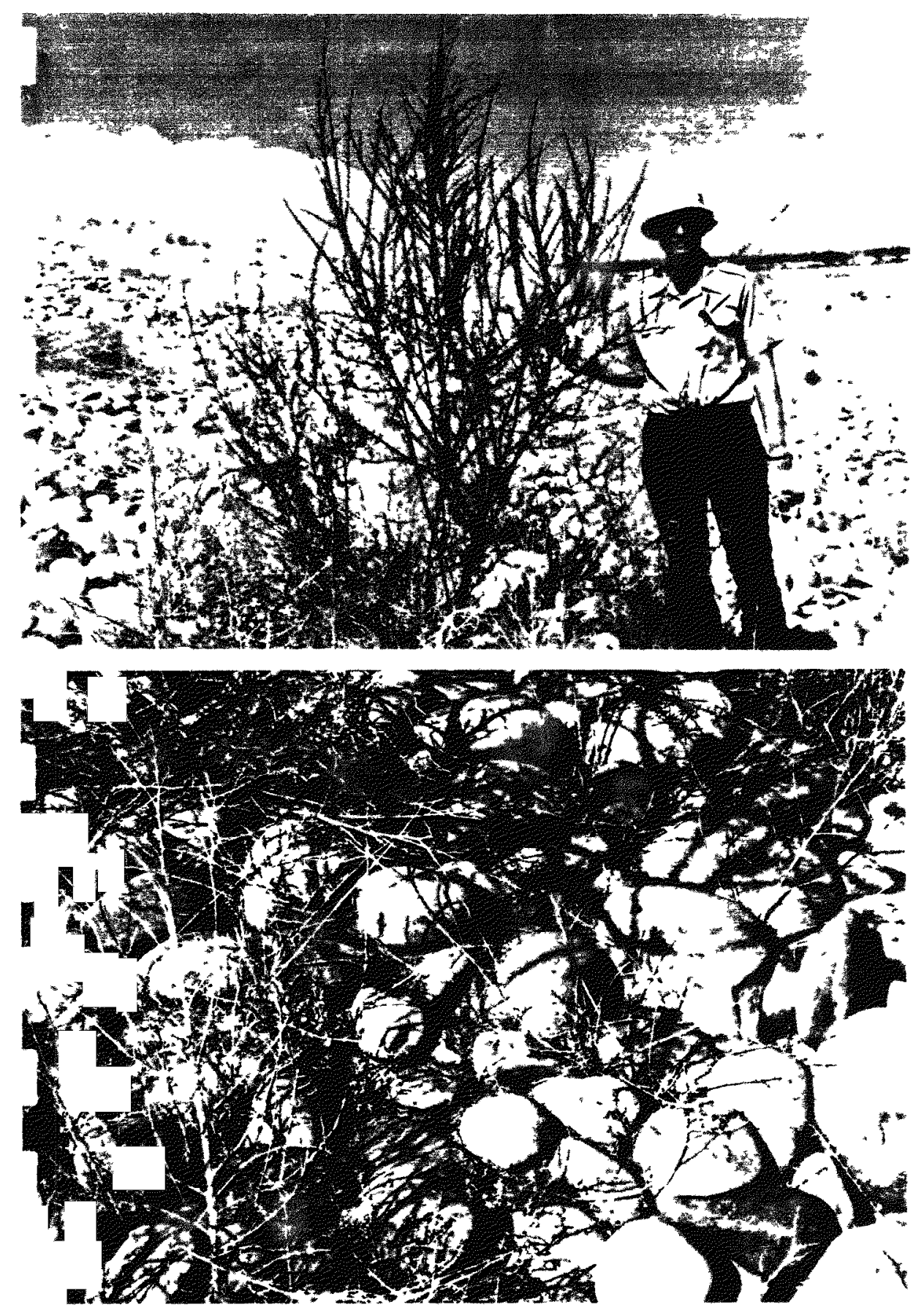

Leaf litter beneath salt cedar on north slope of cell.

Salt cedar excavated from north slope of cell. Notice last year's growth of kochia on cell.

north slope of celt.

Salt cedar excavated on north slope; four-inch diameter and two years old. 
PHOTOGRAPHIC SERIES 4

BURRELL DISPOSAL CELL, 1988, 1989, and 1990 
